\title{
Multimedia Mobile Application of National Heroes History Learning for Children's Character Education
}

Aplikasi Mobile Multimedia Pembelajaran Sejarah Pahlawan Nasional untuk Pendidikan Karakter Anak-Anak

\author{
Anis Susila Abadi ${ }^{1}$, Pipit Febriana Dewi ${ }^{2}$ \\ ${ }^{1,2}$ Informatika, Universitas Nahdlatul Ulama Yogyakarta, Indonesia \\ ${ }^{1}$ anis.abadi@unu-jogja.ac.id, ${ }^{2 *}$ pfdewi@unu-jogja.ac.id
}

\section{Informasi Artikel}

Received: July 2021

Revised: August 2021

Accepted: August 2021

Published: October 2021

\begin{abstract}
Purpose: develope a multimedia application about the history of national heroes from Indonesia.

Design/methodology/approach: the method used is the UCD (User Centered Design) method.

Findings/result: this multimedia mobile application of national heroes history learning for children's character education has succeeded in meeting user needs.

Originality/value/state of the art: a multimedia application about the history of national heroes from Indonesia.
\end{abstract}

\begin{abstract}
Abstrak
Tujuan: mengembangkan sebuah aplikasi multimedia tentang sejarah tokoh pahlawan nasional dari berbagai wilayah di Indonesia.

Perancangan/metode/pendekatan: metode yang digunakan adalah menggunakan metode UCD (User Centered Desain). Hasil: aplikasi mobile multimedia pembelajaran pahlawan nasional untuk pendidikan karakter ini telah berhasil dalam memenuhi kebutuhan pengguna.

Keaslian/ state of the art: aplikasi multimedia tentang sejarah tokoh pahwalan nasional dari berbagai wilayah di Indonesia.
\end{abstract}

\section{Pendahuluan}

Perkembangan arus informasi yang bebas baik melalui berbagai aplikasi yang tersedia pada perangkat cerdas (smartphone) seperti sosial media dan aplikasi permainan telah memberikan dampak pada perkembangan dan pengetahua anak-anak. Saat ini, Anak-anak lebih mengingat sosok-sosok fiksi yang dianggap sebagai pahlawan dibandingkan mengetahui pahlawan nasional Indonesia. Untuk itulah diperlukan suatu media pembelajaran interaktif yang berbasis multimedia untuk dapat menarik minat anak-anak Indonesia untuk mengetahui pahlawan 
nasional Indonesia. Dengan dukungan teknologi diharapkan mampu untuk membantu anakanak Indonesia di dalam mengetahui pahlawan nasional.

Pahlawan Nasional adalah gelar yang diberikan kepada warga negara Indonesia atau seseorang yang berjuang melawan penjajahan di wilayah yang sekarang menjadi wilayah Negara Kesatuan Republik Indonesia yang gugur atau meninggal dunia demi membela bangsa dan negara, atau yang semasa hidupnya melakukan tindakan kepahlawanan atau menghasilkan prestasi dan karya yang luar biasa bagi pembangunan dan kemajuan bangsa dan negara Republik Indonesia. Gelar pahlawan ini meliputi Pahlawan Nasional, Pahlawan Perintis Kemerdekaan, Pahlawan Kemerdekaan, Pahlawan Proklamasi, Pahlawan Kebangkitan Nasional, dan Pahlawan Revolusi. Sampai dengan bulan Agustus 2017 telah ditetapkan 165 tokoh sebagai Pahlawan Nasional.

Sistem pendidikan merupakan kendaraan bagi sebuah bangsa untuk mencapai suatu persatuan dan keselarasan. Proses pendidikan dan pembelajaran kepada anak berjalan sejak dini yaitu sejak anak dilahirkan. Tahap selanjutnya, proses pendidikan tersebut dapat dilakukan melalui jalur formal maupun jalur informal. Pendidikan sejarah mengenai pahlawan nasional perlu dikenalkan pada anak-anak agar memiliki nilai-nilai patriotime dan nasionalisme. Saat ini, teknologi telah mendapatkan perhatian yang meningkat sebagai sarana utama untuk menyediakan berbagai layanan [1]. Pengembangan aplikasi multimedia untuk pendidikan anakanak sangat populer saat ini. Ada banyak keuntungan yang bisa didapat dengan mengembangkan aplikasi tersebut. Termasuk keuntungan yang meliputi peningkatan kinerja belajar anak-anak [2]. Pada kenyataanya, banyak aplikasi dengan berbagai jenis animasi ini tidak semua cocok untuk pendidikan anak-anak [3]. Pembelajaran dengan menggunakan multimedia memiliki keunggulan intuitif, jelas, informative, menarik dan lain sebagainya bila dibandingkan dengan pembelajaran tradisional [4][5] [6]. Teknologi multimedia mengabungkan elemen teks, grafis, audio, video, dan animasi untuk menyampaikan informasi [7][8][9].

Multimedia ini menjadi media yang tepat untuk menerapkan teknologi pembelajaran anak untuk mengenal dan mengetahui para tokoh pahlawan nasional Indonesia. Multimedia interaktif menjadi penting dalam pembelajaran karena terdiri dari komponen-komponen media (tek, gambar, animasi, audio dn video) dirancang untuk saling melengkapi [10]. Multimedia sebagai produk baru dari teknologi modern berusaha melibatkan semua indera, termasuk visual, pendengaran dan perasaan [11] [12]. Terdapat perbedaan yang siginifikan antara anak-anak usia 4-6 tahun dengan orang dewasa terhadap kebutuhan interaksi dan antarmuka aplikasi pembelajaran pada perangkat mobile. Teknologi smartphone yang ada saat ini telah menyediakan berbagai fitur yang dapat mendukung instalasi berbagai aplikasi untuk berbagai kebutuhan kegiatan belajar [13] [14]. Perusahaan pengembang software (aplikasi pembelajaran anak-anak) harus memperhatikan kebutuhan anak-anak terhadap desain aplikasi pendidikan yang sesuai untuk anak-anak [15]. Salah satu metode yang dapat digunakan dalam perancangan aplikasi adalah metode User Centered Design (UCD). Metode UCD ini menekankan perancangan berdasarkan pada kebutuhan user.

Banyak metode dikembangankan untuk dapat menghasilkan sebuah aplikasi yang dapat memenuhi kebutuhan pengguna dengan kualitas yang baik. UCD (User Centered Design) sebagai salah satu metode dalam pengembangan mobile application untuk menghasilkan sebuah aplikasi yang sesuai dengan kebutuhan pengguna. Dengan mendasarkan pada konteks kegunaan, sebuah aplikasi mobile dapat dirancang berdasarkan model UCD Proses. Dari konteks kegunaan, aplikasi dirancang berdasarkan 6 tahap yaitu plan user centered design 
process, specify context of use, specify user requirement, produce design solution, evaluate desaign, dan implementation system.

Dalam penelitian ini, penulis mengusulkan aplikasi mobile multimedia pembelajaran sejarah pahwalan nasional untuk pendidikan karakter anak-anak. Penelitian ini dilakukan untuk mengembangkan sebuah aplikasi multimedia tentang sejarah tokoh pahwalan nasional dari berbagai wilayah di Indonesia. Metode yang digunakan dalam perancangan ini adalah metode UCD.

\section{Metode/Perancangan}

Pada metode dibahas tentang metode, tahapan, maupun model yang digunakan dalam penelitian yang dilakukan.

Penelitian Aplikasi multimedia pengenalan tokoh pahlawan ini merupakan penelitian untuk menghasilkan aplikasi teknologi informasi dan multimedia dalam bidang pembelajaran untuk anak-anak. Metode yang digunakan adalah menggunakan metode UCD (User Centered Desain). Metode ini merupakan metode perancangan perangkat lunak yang berfokus pada pengguna. Tahapan metode UCD dapat dilihat seperti pada gambar 1.

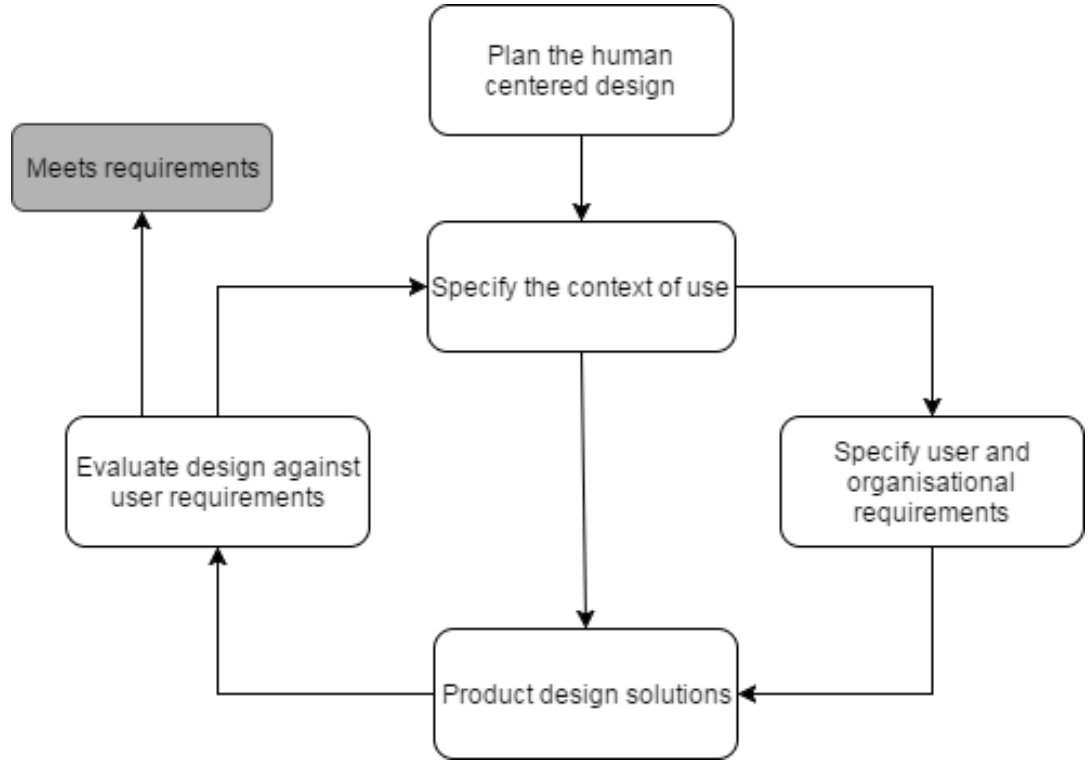

Gambar 1. Tahapan Metode UCD (User Centered Design)

Pada gambar 1 diatas terlihat bahwa metode pengembangan aplikasi ini terdiri dari enam tahap.

a. Plan User Centered Design Process

Tahap ini merupakan tahap untuk melakukan identifikasi dan menentukan siapakah yang akan menjadi pengguna dari aplikasi mobile multimedia pembelajaran sejarah pahlawan nasional untuk pendidikan karakter anak-anak.

b. Specify Context of Use 
Kegiatan dalam tahap ini adalah melakukan identifikasi karakteristik pengguna yang telah ditentukan pada tahap sebelumnya. Melakukan identifikasi bagaimana keinginan atau orientasi pengguna terhadap sebuah aplikasi agar aplikasi sukses dibuat.

c. Specify User Requirement

Tahap spesifikasi user requirement ini adalah tahap untuk melakukan identifikasi apa saja yang pengguna butuhkan terhadap aplikasi.

\section{d. Produce Design Solution}

Setelah tiga tahap sebelumnya selesai dilakukan, pada bagian ini dilakukan perancangan desain secara lengkap. Pada tahap ini dilakukan pembuatan desain storyboard untuk aplikasi mobile multimedia pembelajan anak sholeh. Dalam melakuan desain antarmuka dan konten ini mempertimbangkan komponen multimedia yang terdiri dari teks, suara, gambar, video, dan animasi.

\section{e. Evaluate Design}

Tahap evaluate design merupakan tahap untuk melakukan evaluasi terhadap hasil rancangan. Apabila hasil evaluasi menunjukan telah terpenuhinya seluruh kebutuhan maka dapat dilanjutkan pada tahap implementasi tetapi apabila hasil evaluasi memberikan rekomendasi untuk dilakukan perbaikan maka kegiatan akan kembali pada tahap specify context of use. Kegiatan-kegiatan tersebut terus berkesinambungan sampai mendapatkan sebuah desain yang memenuhi seluruh kebutuhan.

\section{f. Implemenatation}

Setelah mendapatkan desain yang sesuai dan memenuhi seluruh kebutuhan pengguna, tahap berikutnya adalah implementasi sistem. Aplikasi multimedia pengenalan tokoh pahlawan untuk anak-anak di produksi sesuai dengan rancangan dan diimplementasikan untuk digunakan kepada anak-anak.

\section{Hasil dan Pembahasan (Heading 1)}

\subsection{Plan The User Centered Design}

Pengguna dari aplikasi mobile multimedia pembelajaran sejarah pahlawan nasional untuk pendidikan karakter anak-anak yaitu anak-anak pada rentang usia 8-13 tahun sebagaimana usia anak-anak sebagai siswa sekolah dasar. Anak-anak pada rentang tersebut merupakan pengguna yang memiliki karakteristik untuk menjadi pertimbangan dalam menentukan suatu rancangan apliaksi pembelajaran multimedia berbasis mobile ini.

\subsection{Specify Comtext of use}

Pada tahap ini telah di pilih secara acak 10 orang anak-anak dalam usia 8-13 tahun kemudian dilakukan observasi dan wawancara mengenai karakteristik dari anak-anak tersebut dan ketertarikannya pada suatu antarmuka apliaksi. Hasil observasi dan wawancara diperoleh data sebagaimana pada tabel 1 berkut ini.

Tabel 1. Data Karakteristik Pengguna

\begin{tabular}{|l|l|l|}
\hline No & Keterangan & Hasil \\
\hline 1 & $\begin{array}{l}\text { Gadget yang } \\
\text { digunakan }\end{array}$ & $\begin{array}{l}\text { 6 orang milik sendiri } \\
\text { 4 orang milik orang tua }\end{array}$ \\
\hline 2 & $\begin{array}{l}\text { Waktu penggunaan } \\
\text { gadget }\end{array}$ & 4 orang menggunakan gadget lebih dari 5 jam sehari \\
\hline
\end{tabular}




\begin{tabular}{|l|l|l|}
\hline & & $\begin{array}{l}3 \text { orang menggunakan gadget 3-5 jam sehari } \\
3 \text { orang menggunakan gadget 2-3 jam sehari }\end{array}$ \\
\hline 3 & $\begin{array}{l}\text { Aplikasi yang sering } \\
\text { digunakan }\end{array}$ & $\begin{array}{l}\text { 1. Game } \\
\text { 2. Yotube } \\
\text { WA }\end{array}$ \\
\hline 4 & $\begin{array}{l}\text { Warna layout } \\
\text { antarmuka apliaksi }\end{array}$ & 10 orang menyukai warna cerah \\
\hline 5 & Layout menu & 10 menyukai menu bergambar daripada tulisan \\
\hline 6 & Bentuk tombol & 10 orang menyukai tombol dalam bentuk grafis \\
\hline 7 & Interaksi & $\begin{array}{l}10 \text { orang menyukai interaksi aplikasi dalam bentuk grafis dan } \\
\text { suara. }\end{array}$ \\
\hline
\end{tabular}

\subsection{Spesify User Requirment}

Pada tahap ini dilakukan identifikasi kebutuhan terhadap aplikasi sesuai dengan tujuan pengembangan. Hasil dari tahapan ini adalah spesifikasi kebutuhan dalam bentuk kebutuhan fungsional dan kebutuhan non fungsional dari aplikasi yang akan dibuat.

a. Kebutuhan fungsional

1) Aplikasi dapat menampilkan nama-nama pahlawan nasional dan sejarahnya yang di sajikan berdasarkan wilayah nusantara.

2) Aplikasi dapat menampilkan salah satu permainan yang dapat digunakan untuk melatih kemampuan berpikir dalam mengenali tokoh pahlawan nasional (game puzle).

3) Aplikasi dapat memberikan tantangan sebagai kuis untuk mengukur tingkat kemampuan pengguna dalam memahami tokoh pahlawan nasional.

4) Aplikasi dapat menampilkan materi tentang pancasila sebagai dasar negara Republik Indonesia.

5) Materi sejarah pahlawan nasional disajikan dalam bentuk multimedia dengan komponen gambar, animasi, dan suara narasi.

b. Kebutuhan non fungsional

1) Aplikasi dibuat untuk dapat berjalan di perangkat mobile dengan sistem operasi android

2) Aplikasi dapat dijalankan tanpa harus terhubung melalui jaringan internet

3) Aplikasi dapat digunakan tanpa harus melakukan pendaftaran pengguna

4) Aplikasi secara aman dapat digunakan oleh anak-anak

\subsection{Produce Desain Solution}

\subsubsection{Usecase diagram}

Untuk membantu proses perancangan dalam mendeskripsikan interaksi antara pemgguna dengan sistem maka dibuat sebauah usecase diagram. Usecase diagram dari aplikasi ini terlihat pada gamba 2 berikut ini. 


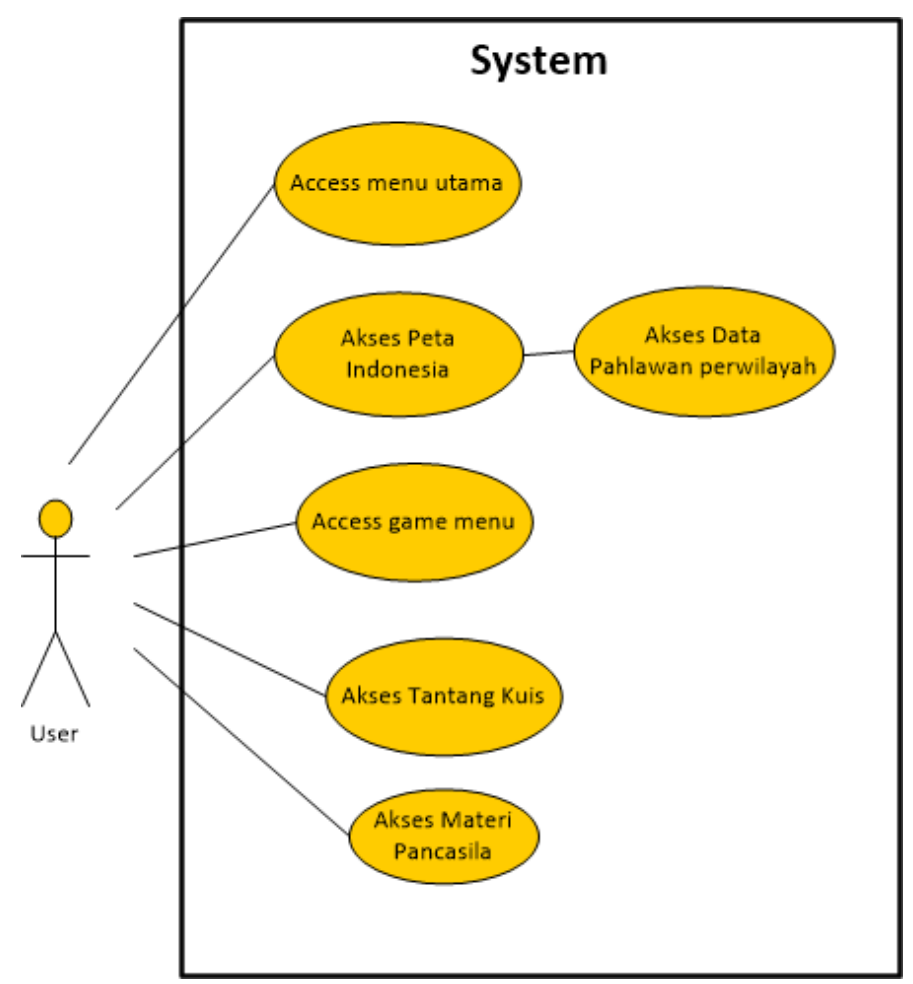

Gambar 2. Usecase Diagram Aplikasi

\subsubsection{Diagram activity}

Diagram activity ini merupakan diagram yang digunakan untuk menggambarkan aktifitas di dalam sistem aplikasi mobile multimedia pembalaran sejarah pahlawan nasional untuk anakanak. Terdapat interaksi antara user dengan sistem aplikasi yang digambarkan pada diagram ini. Diagram activity terlihat pada gambar 3 berikut ini. 

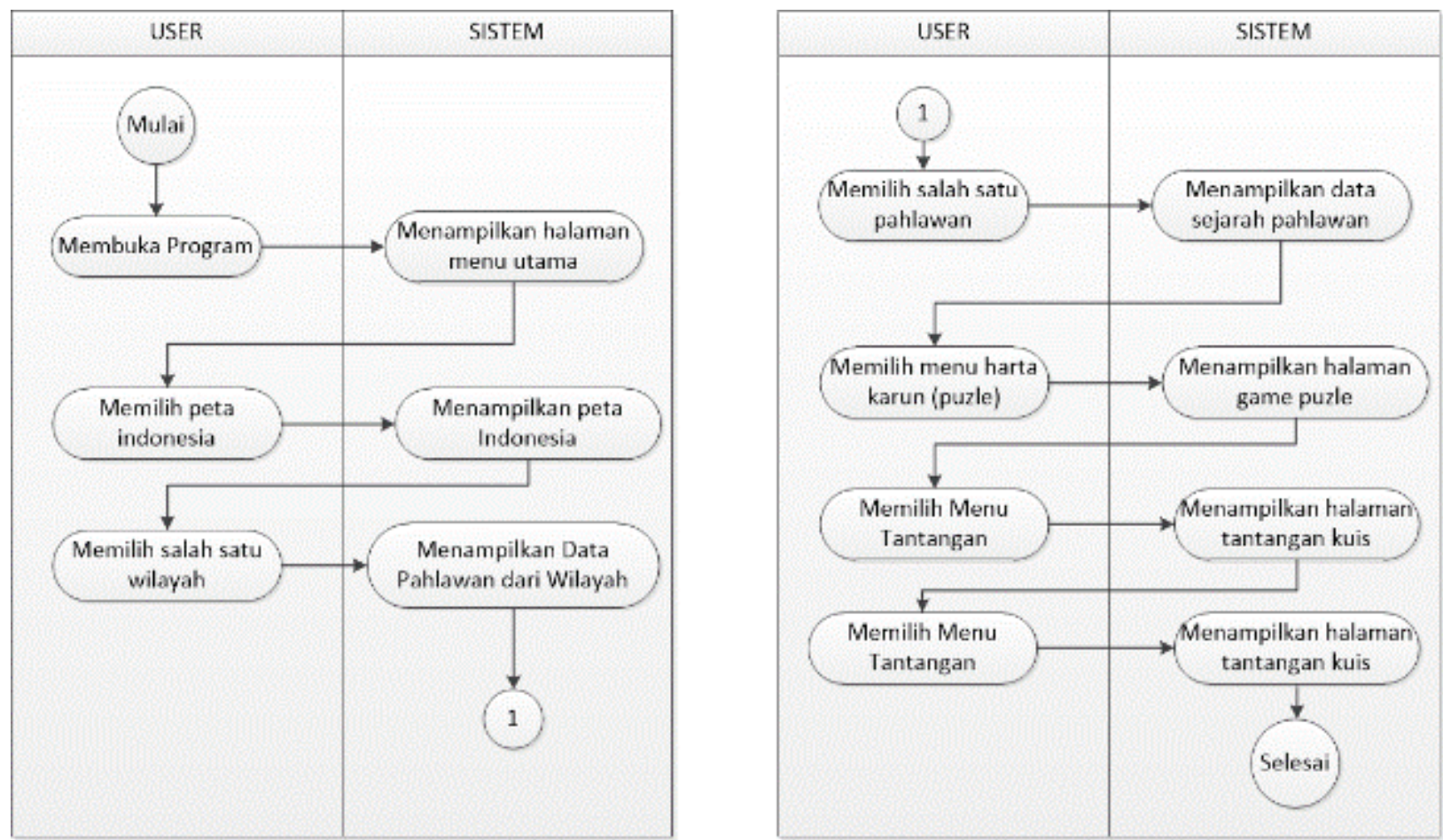

Gambar 3. Diagram Activity pada Aplikasi

\subsubsection{Struktur menu}

Strutur menu merupakan fasilitas interaksi antar user dengan aplikasi. Struktur menu dirancang untuk sesuai dengan diagram activity yang telah dibuat. Struktur menu pada aplikasi mobile multimedia pembelajaran sejarah pahlawan nasional ini dapat dilihat pada gambar 4 .

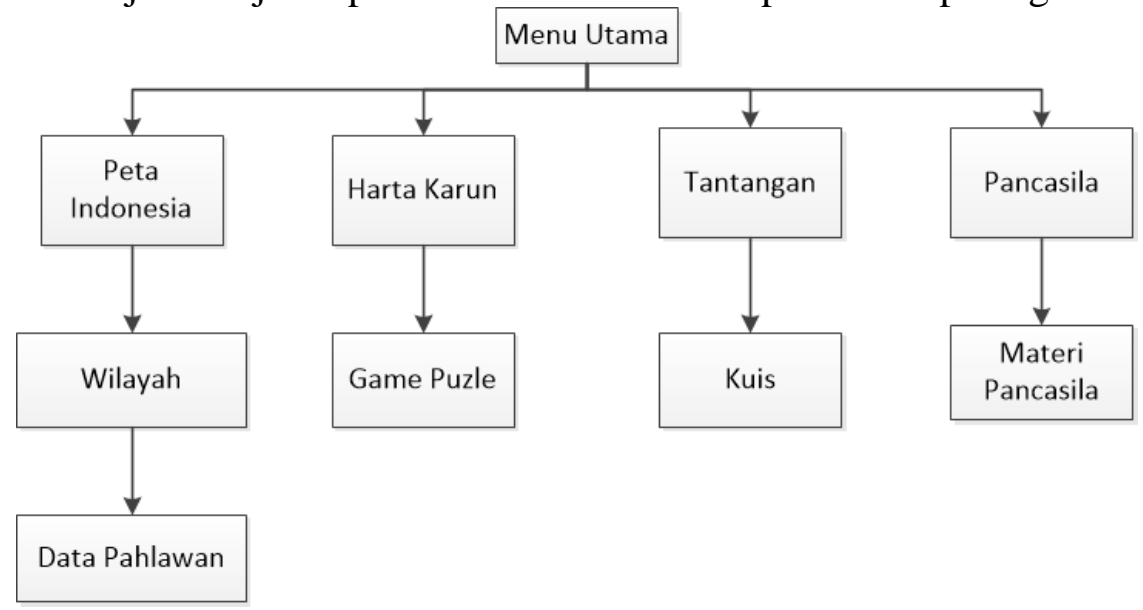

Gambar 4. Strukur Menu Aplikasi

\subsubsection{Rancangan antarmuka}

Antarmuka merupakan tampilan program aplikasi yang terlihat oleh pengguna. Racangan antar muka aplikasi mobile multimedia pembelajaran sejarah pahlawan nasional untuk anakanak ini terdiri dari beberapa halaman yang dapat diakses melalui menu utama. Rancangan antarmuka aplikasi ini dapat dilihat pada gambar 5 . 

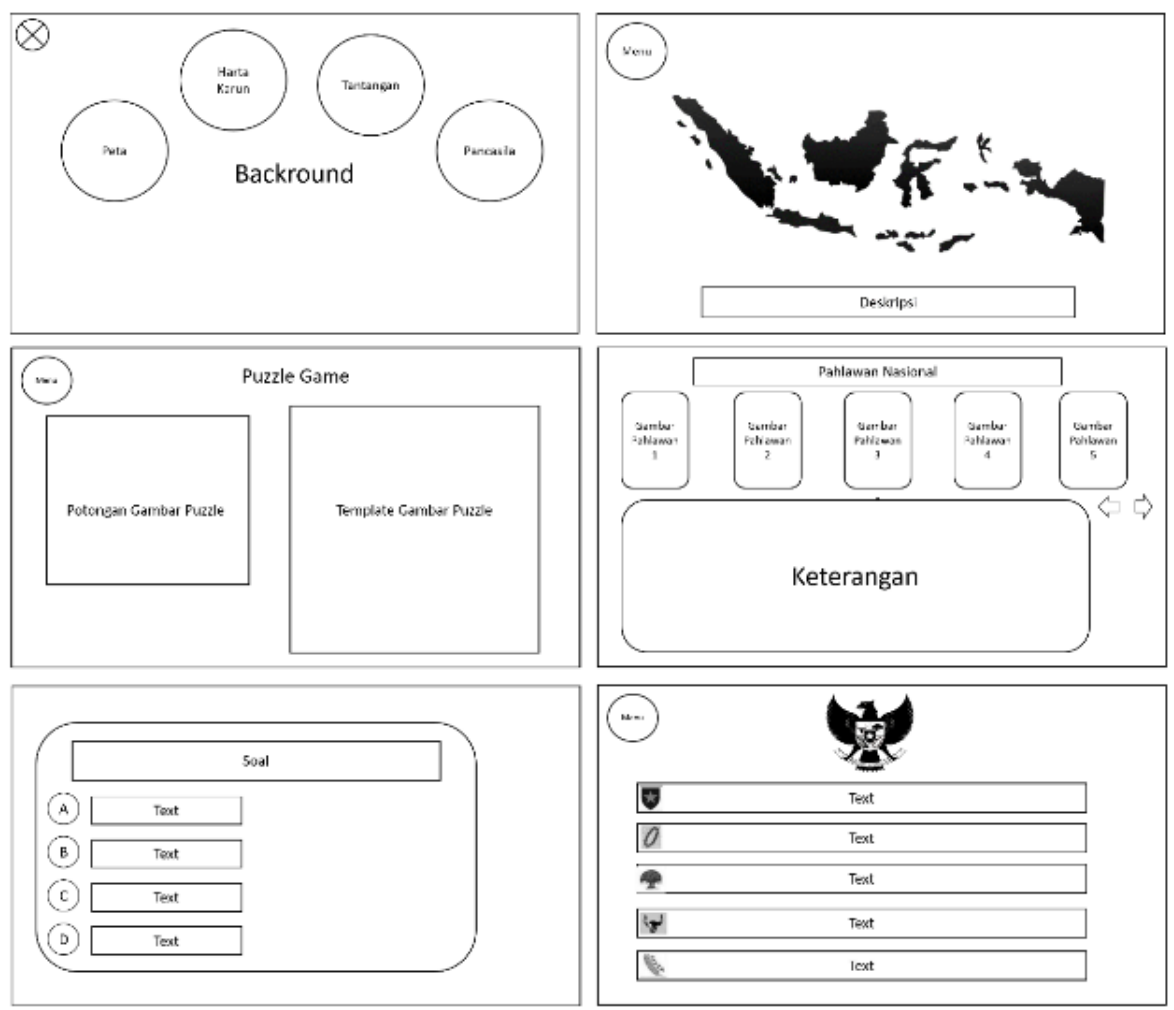

Gambar 5. Rancangan Antarmuka Aplikasi

\subsubsection{Implementation design}

Halaman menu utama merupakan halaman yang petama kali akan muncul dan diakses oleh pengguna aplikasi mobile multimedia pembelajaran sejarah nasional untuk pendidikan karakter anak-anak. Halaman menu utama di tunjukkan pada gambar 6 berikut ini.

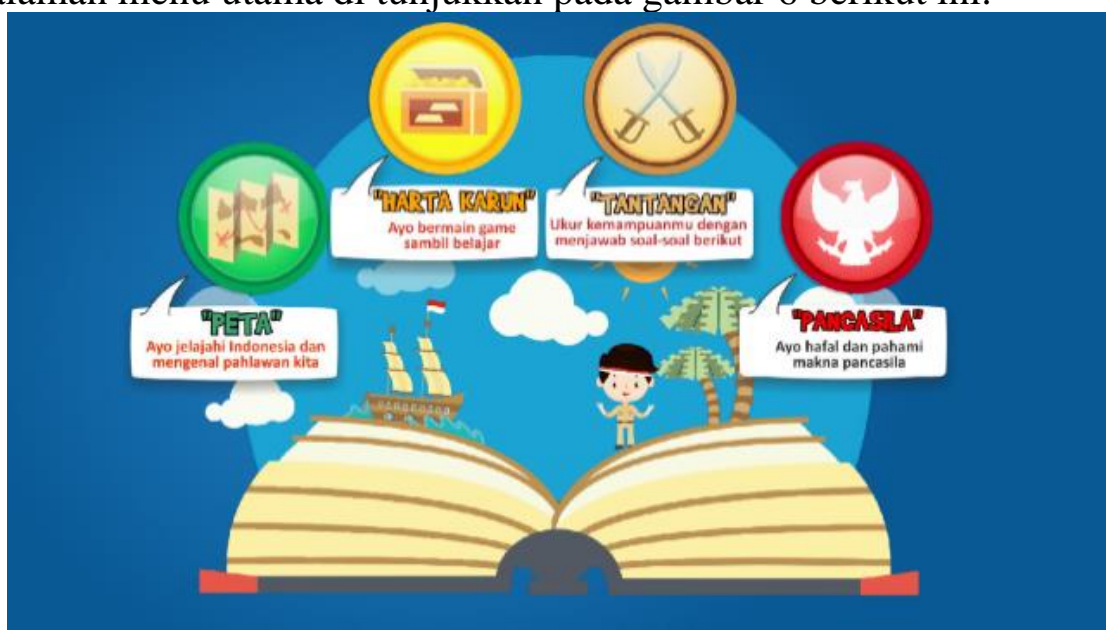

Gambar 6. Halaman Menu Utama

Halaman menu utama ini menampilkan empat buah menu utama dalam bentuk grafik yang difungsikan sebagai tombol dan di berikan label sebagai keterangan. Tombol pada menu utama ini adalag tombol peta, tombo harta karus, tombol tantangan, dan tombol pancasila. Dengan 
memilih salah satu tombol menu ini maka pengguna akan di arahkan ke halaman yang lain sesuai dengan menu tersebut.

Peta Indonedia menampilkan berbagai wilayah indonesi yang meliputi pulau sumater, kalimantan, jawa, bali, sulawesi, maluku, nusa tenggara, dan papua. Tampilan dari halaman peta indonesia ini terlihat pada gambar 7 berikut ini.

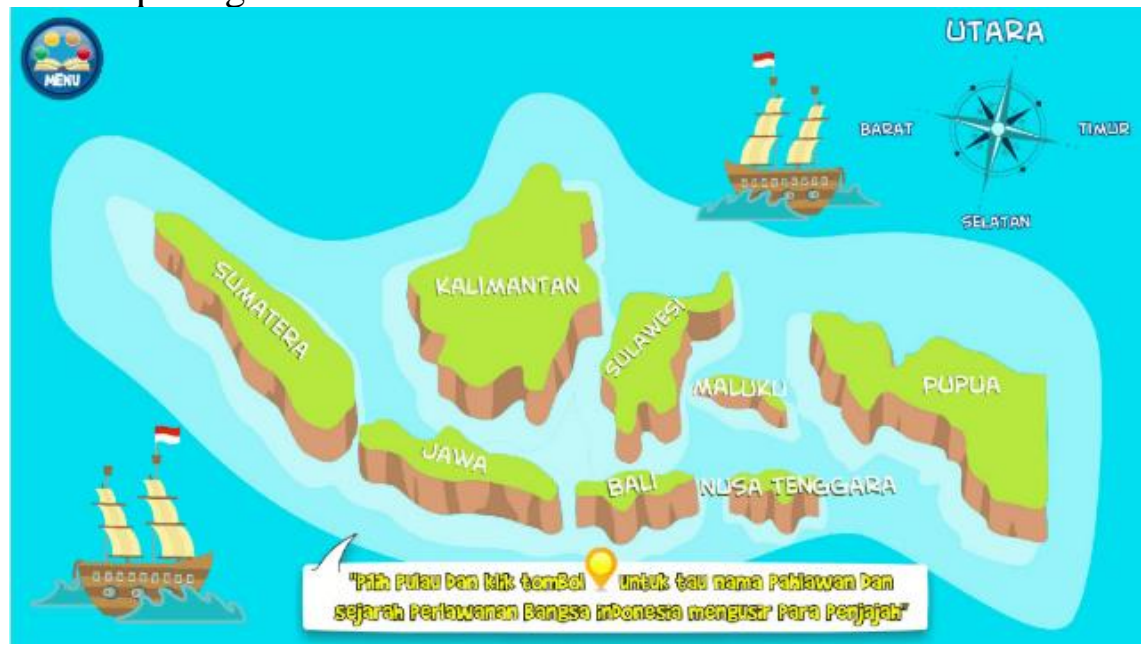

Gambar 7. Halaman Peta Indonesia

Halaman data pahlawan nasional adalah halaman yang berfungsi untuk menempilkan data pahlawan nasional yang berasal dari suatu lokasi tertentu yang dipilih oleh pengguna. Sebagai contoh misalnya seorang pengguna yang memilih pulau sumatera kemudian memilih lokasi sumatera barat maka aplikasi akan menampilkan data pahlawan nasional yang berasal dari sumatera barat. Gambar 8 adalah halaman data pahlawan nasional dari sumatera barat.

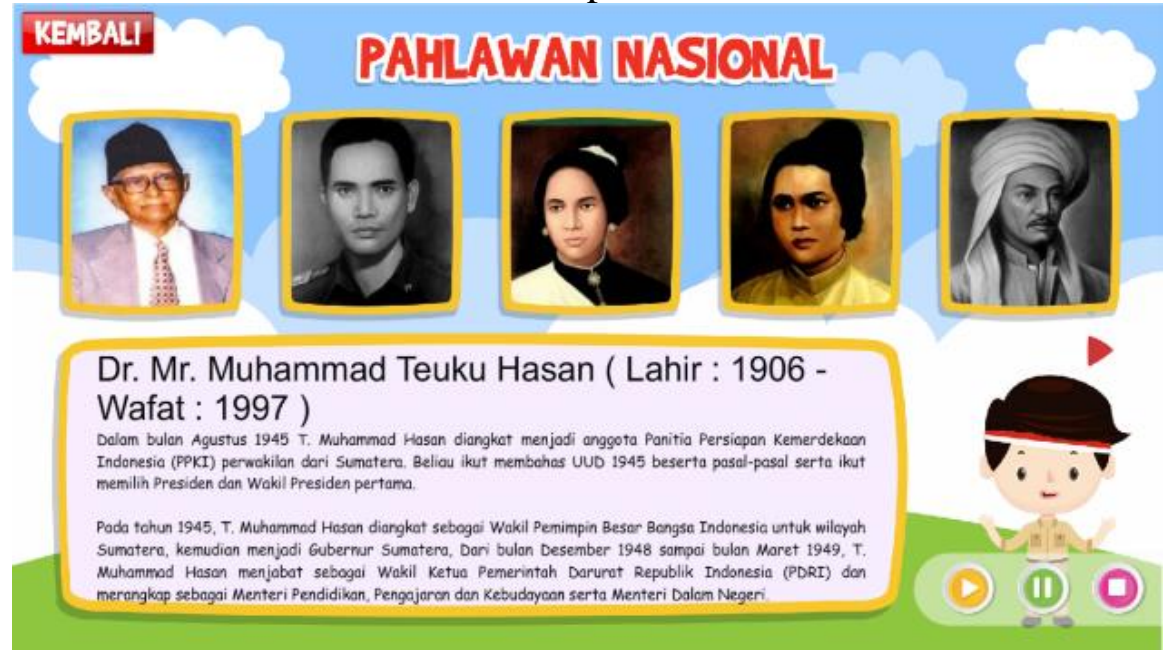

Gambar 8. Halaman Pahhlawan Nasional

Halaman permainan atau game puzle merupakan halaman yang tampil ketika pengguna memilih memu harta karun. Melalui halaman game puzle, pengguna akan diminta unntuk menyusun potongan gambar menjadi satu pada tempat yang telah disediakan sehingga menjadi satu gambar 
tokoh pahlawan nasional. Tampilan dari halaman game puzle ini ditunjukkan pada gambar 9 berikut ini.

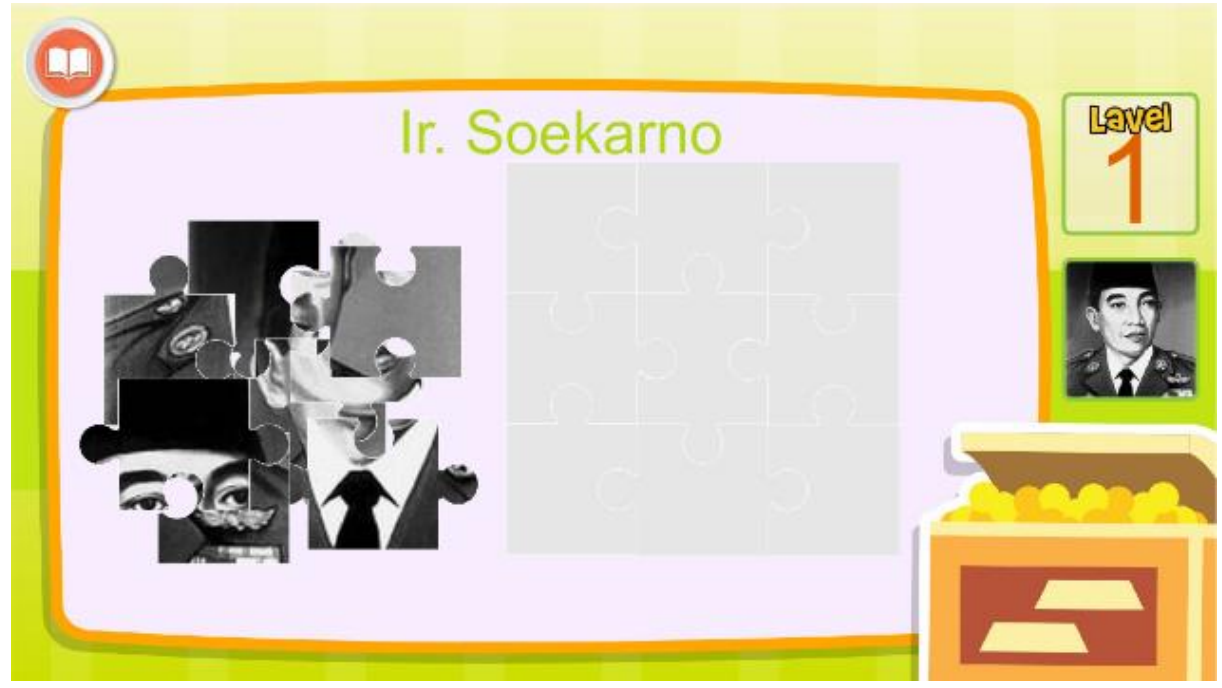

Gambar 9. Halaman Permainan Puzle

Halaman kuis merupakan halaman yang tampil ketika pengguna memilih menu tantangan. Halaman kuis akan menampilkan beberapa pertanyaan yang harus dijawab oleh pengguna dan kemudian akan menampilkan skor nilai untuk mengukur kemampuan pengguna dalam menjawab kuis tantangan. Halaman kuis tantangan ditunjukkan pada gambar 10 berikut ini.

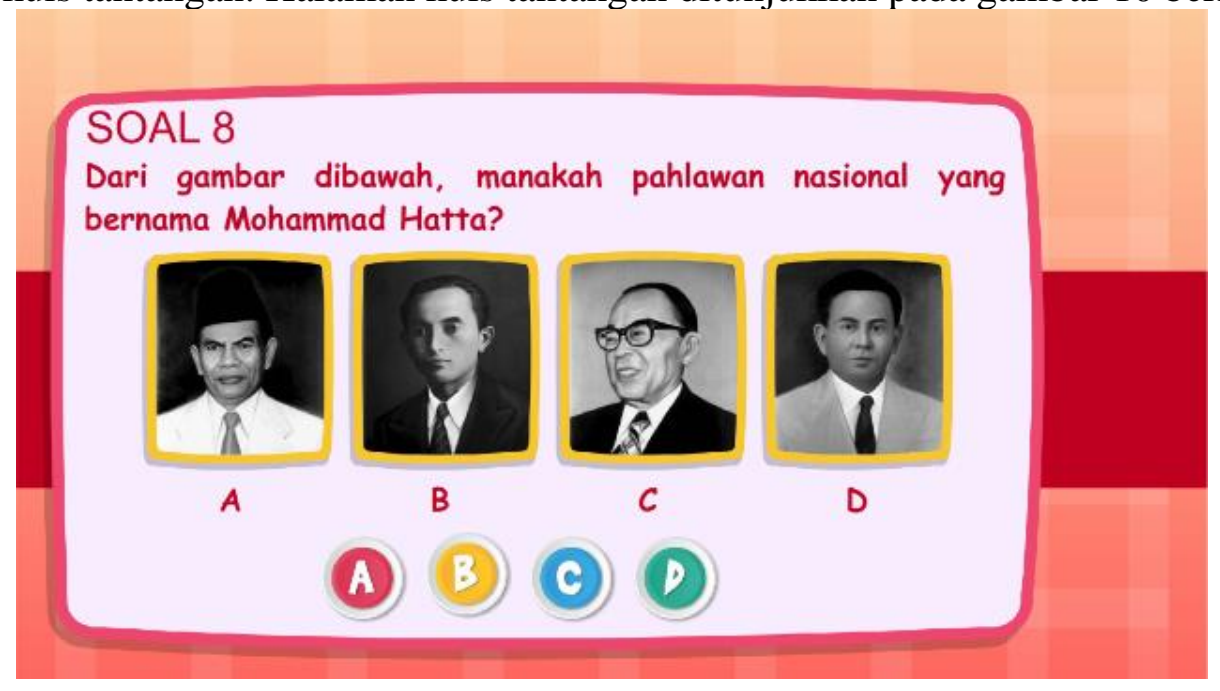

Gambar 10. Halaman Permainan Kuis

Halaman materi pancasila adalah halaman yang tampil ketika pengguna memilih menu pancasila pada hamalan utama. Halaman mateir pancasila ini ditunjukan pada gambar 11 berikut ini. 


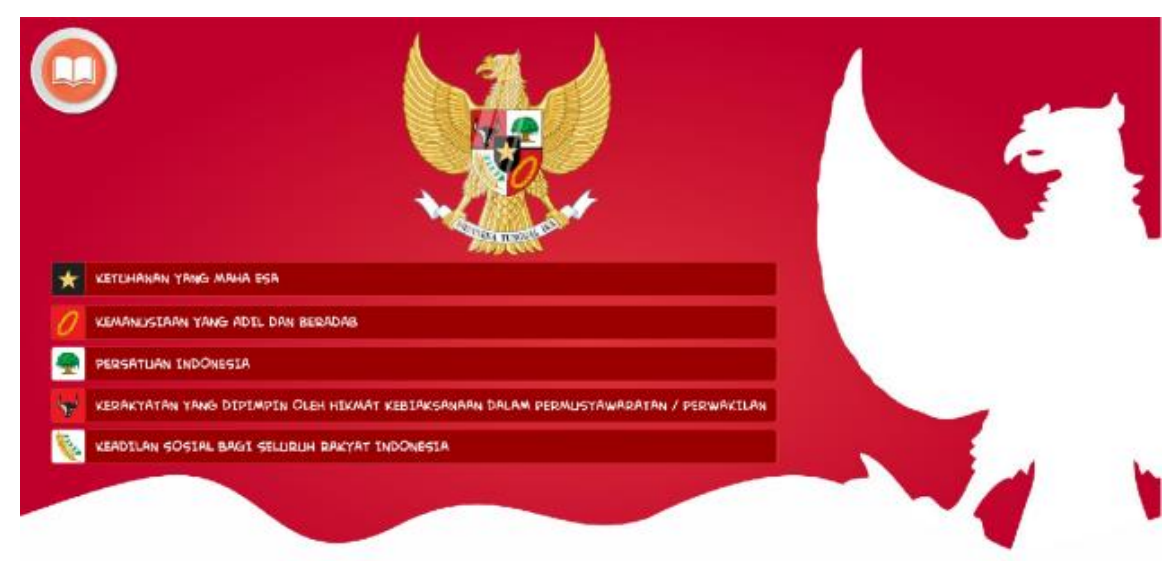

Gambar 10. Halaman Permainan Kuis

\subsection{Evaluate Design}

Tujuan dari pengujian ini adalah untuk mengetahui apakah apalikasi yang dibut telah memenuhi kebutuhan pengguna atau belum. Pada pengujian dilakukan dengan dua teknik pengujian yaitu pengujian kelayakan media pen pengujian usability. Pengujian kelayakan media dilakukan untuk menguji apakah multimedia pembelajaran ini telah sesuai dengan tujuan pembuatan aplikasi atau belum. Selain itu juga untuk mengukur cakupan materi dan kualitas isi dari media. Pengujian kelayakan media dilakukan oleh ahli multimedia. Pengujian kelayakan media dilakukan oleh 3 orang dengan menjawab kuisioner yang memiliki 21 pertanyaan sebagai indikator. Setiap pertanyaan memiliki jawaban dalam skala likerd 1 sampai dengan 5 yang menunjukan bobot dari pertanyaan tersebut. Tabel 2 berikut ini adalah hasil pengujian kelayakan media.

Tabel 1. Hasil Evaluasi Kelayakan Media

\begin{tabular}{|l|l|c|}
\hline No & Pertanayan & Skor \\
\hline 1 & Kemudahan navigasi yang disajikan & 4,33 \\
\hline 2 & Ketepatan navigasi dengan menu yang diinginkan & 5 \\
\hline 3 & Kemudahan pengoperasian media & 5 \\
\hline 4 & Keterkaitan gambar dengan materi & 4,66 \\
\hline 5 & Kejelasan suara & 4 \\
\hline 6 & Tingkat volume suara & 4,33 \\
\hline 7 & Kualitas suara & 4 \\
\hline 8 & Kualitas teks & 4,66 \\
\hline 9 & Keterbacaan tulisan (teks) & 4,33 \\
\hline
\end{tabular}




\begin{tabular}{|c|l|c|}
\hline 10 & Ketepatan ukuran huruf & 4,66 \\
\hline 11 & Ketepatan warna huruf & 4,33 \\
\hline 12 & Ketepatan jenis huruf & 4,66 \\
\hline 13 & Kejelasan tata letak gambar & 4,33 \\
\hline 14 & Kesesuaian tampilan & 4,66 \\
\hline 15 & Ketepatan penggunaan tema & 4,33 \\
\hline 16 & Penempatan konten & 4,66 \\
\hline 17 & Kualitas tampilan design & 4,33 \\
\hline 18 & Penyajian bersifat simetris & 4,66 \\
\hline 19 & Kesesuaian warna tulisan dengan background & 4,33 \\
\hline 20 & $\begin{array}{l}\text { Kemudahan pemilihan jawaban pada menu } \\
\text { evaluasi }\end{array}$ & 4,66 \\
\hline 21 & Kemudahan dalam memindah gambar puzle & 4,66 \\
\hline \multicolumn{2}{|l|}{ Skor Rata-Rata } & $\mathbf{4 , 5 0}$ \\
\hline
\end{tabular}

Berdasarakan data hasil evaluasi kelayakan media yang disajikan pada tabel 2, Apliaksi mobile multimedia pembelajaran pahlawan nasional ini memperoleh skor 4,50 dari sekala 5. Hasil ini memnunjukan bahwa aplikasi yang dikembangkan merupakan aplikasi yang layak digunakan sebagai media untuk pembelajaran pahlawan nasional untuk pendidikan karakter anak-anak.

Selain pengujian kelayakan media, pada penelitian ini juga dilakukan pengujian usability. Pengujian usability di gunakan untuk mengukur efektifitas penggunakan. Pengujian usability menggunakan metode SUS (System Usability Scale). Pengujian usability dilakukan oleh 10 orang pengguna. Skenario pengujian usability adalah 10 orang pengguna diminta untuk menjalankan aplikasi mobile multimedia pembelajaran pahlawan nasional. Setelah selesai melakukan domantrasi penggunaan aplikasi, pengguna diminta untuk menjawab kuisioner SUS yang teridri dari 10 butir pertanyaan. Setiap pertanyaan memiliki jawaban dalam skala likerd 15. Tabel 3 berikut ini adalah kuisioner pada pengujian SUS.

Tabel 3. Pertanyaan SUS

\begin{tabular}{|l|l|}
\hline No & Pertanayan \\
\hline 1 & Saya berpikir bahwa saya akan ingin lebih sering menggunakan aplikasi ini \\
\hline 2 & Saya menemukan bahwa aplikasi ini tidak harus serumit ini \\
\hline 3 & Saya pikir aplikasi ini mudah digunakan \\
\hline 4 & $\begin{array}{l}\text { Saya pikir bahwa saya akan membutuhkan bantuan dari orang } \\
\text { teknis untuk dapat menggunakan aplikasi ini }\end{array}$ \\
\hline
\end{tabular}




\begin{tabular}{|c|c|}
\hline \multirow[t]{2}{*}{5} & Saya menemukan berbagai fungsi diaplikasi ini diintergrasikan dengan baik \\
\hline & Saya pikir ada terlalu banyak ketidaksesuaian dalam aplikasi ini \\
\hline 7 & $\begin{array}{l}\text { Saya } \\
\text { orang akan mudah untuk mempelajari aplikasi ini dengan sangat cepat }\end{array}$ \\
\hline 8 & Saya menemukan aplikasi ini sangat rumit untuk digunakan \\
\hline 9 & Saya merasa sangat percaya diri untuk menggunakan aplikasi ini \\
\hline 10 & $\begin{array}{l}\text { Saya perlu belajar banyak hal sebelum saya bisa } \mathrm{m} \\
\text { aplikasi ini }\end{array}$ \\
\hline
\end{tabular}

Jawaban dari kuisioner SUS tersebut adalah skala likerd 1-5. Untuk setiap responden, skor dari setiap pertanyaan kemudian di jumahkan. Skor hasil dari pengujian SUS ini disajikan pada tabel 4.

Tabel 4. Hasil Pengujian SUS

\begin{tabular}{|l|l|l|l|}
\hline No & Responden & $\begin{array}{c}\text { Jumlah } \\
\text { Skor }\end{array}$ & $\begin{array}{c}\text { Nilai } \\
\text { (jumlah } \\
\mathbf{* 2 , 5})\end{array}$ \\
\hline 1 & Responden 1 & 31 & 77,5 \\
\hline 2 & Responden 2 & 31 & 77,5 \\
\hline 3 & Responden 3 & 33 & 82,5 \\
\hline 4 & Responden 4 & 30 & 75 \\
\hline 5 & Responden 5 & 31 & 77,5 \\
\hline 6 & Responden 6 & 27 & 67,5 \\
\hline 7 & Responden 7 & 30 & 75 \\
\hline 8 & Responden 8 & 29 & 72,5 \\
\hline 9 & Responden 9 & 30 & 75 \\
\hline 10 & Responden 10 & 31 & 77,5 \\
\hline Skor Rata-Rata & & $\mathbf{7 5 , 7 5}$ \\
\hline
\end{tabular}

Berdasarkan pada hasil perhitungan skor SUS, Aplikasi mobile multimedia pembelajaran sejarah pahlawan nasional untuk pendidika karakter memperoleh hasil penilai sebesar 75,75. Mengacu pada nilai standart dari metode SUS maka aplikasi mobile multimedia pembalajaran sejarah pahlawan nasional untuk pendidikan karakter anak-anak ini merupakan aplikasi yang masuk pada kategori Acceptable (dapat diterima) dengan kualitas good (bagus). 


\section{Kesimpulan dan Saran}

Aplikasi mobile multimedia pembelajaran sejarah pahlawan nasional ini telah berhasil dikembangkan dengan menggunakan metode UCD (User Centered Desain). Dari tahapan UCD ini, tahap menentukan pengguna, identifikasi pengguna, dan identifikasi kebutuhan merupakan tahapan yang penting dalam menentukan desain dari aplikasi ini. Aplikasi mobile multimedia pembelajaran sejarah pahlawan nasional untuk pendidikan karakter anak-anak ini telah melalui tahapan pengujian dengan pengujian kelayakan media dan pengujian usability. Pada pengujian kelayakan media, apliakasi ini memeperoleh skor 4,50 dari skala 5 yang berarti bahwa aplikasi ini telah layak untuk digunakan dan memenuhi kebutuhan. Berdasarkan pada pengujian usability menggunakan metode SUS, aplikasi ini memperoleh skor 75,75 yang menunjukkan bahwa aplikasi ini masuk dalam kategor acceptable atau dapat di terima dengan peringkat good atau bagus. Berdasarkan hasil pengujian tersebut maka aplikasi mobile multimedia pembelajaran pahlawan nasional untuk pendidikan karakter ini telah berhasil dalam memenuhi kebutuhan pengguna.

\section{Daftar Pustaka}

[1] E. A. Khan and M. K. Y. Shambour, "An analytical study of mobile applications for Hajj and Umrah services," Applied Computing and Informatics. 2018.

[2] K. Chachil, A. Engkamat, A. Sarkawi, and A. R. A. Shuib, "Interactive Multimedia-based Mobile Application for Learning Iban Language (I-MMAPS for Learning Iban Language)," Procedia - Soc. Behav. Sci., vol. 167, pp. 267-273, 2015.

[3] N. Ibrahim, W. F. Wan Ahmad, and A. Shafie, "Multimedia mobile learning application for children???s education: The development of MFolktales," Asian Soc. Sci., vol. 11, no. 24, pp. 203-215, 2015.

[4] X. Xu, "Study on effective using of multimedia teaching system and enhancing teaching effect," Int. J. Emerg. Technol. Learn., vol. 12, no. 6, pp. 187-195, 2017.

[5] R. Pittschellis, "Multimedia support for learning factories," Procedia CIRP, vol. 32, no. Clf, pp. 36-40, 2015.

[6] N. Cavus, "Development of an Intellegent Mobile Application for Teaching English Pronunciation," in Procedia Computer Science, 2016.

[7] O. D. Omodara and E. I. Adu, "Relevance of Educational Media and Multimedia Technology for Effective Service Delivery in Teaching and Learning Processes," IOSR J. Res. Method Educ., vol. 4, no. 2, pp. 48-51, 2014.

[8] T. Susilowati et al., "Learning application of Lampung language based on multimedia software," Int. J. Eng. Technol., vol. 7, no. 2.27, p. 175, 2018.

[9] R. E. Mayer, "Using multimedia for e-learning," J. Comput. Assist. Learn., vol. 33, no. 5, pp. 403-423, 2017.

[10] R. Rachmadtullah, Z. MS, and M. Syarif Sumantri, "Development of computer-based interactive multimedia : study on learning in elementary education," Int. J. Eng. Technol., vol. 7, no. 4, p. 2035, 2018.

[11] C. Anugrah Putra, "Use of Multimedia Learning Technology Based Graphical User Interface (GUI)," Adv. Soc. Sci. Educ. Humanit. Res. (ASSEHR), Vol. 88 3rd NFE Conf. Lifelong Learn. (NFE 2016), vol. 88, no. Nfe 2016, pp. 1-5, 2017.

[12] N. Sakamat, S. N. Sabri, and N. Mat Diah, "Multimedia Elements of Digital Storytelling 
for Dyslexic Children,” Sci. Res. J., vol. 14, no. 2, p. 35, 2019.

[13] I. K. Yusri, R. Goodwin, and C. Mooney, "Teachers and Mobile Learning Perception: Towards a Conceptual Model of Mobile Learning for Training," Procedia - Soc. Behav. Sci., vol. 176, pp. 425-430, 2015.

[14] M. Saefi, B. Lukiati, and E. Suarsini, "Developing Android-Based Mobile Learning On Cell Structure And Functions Lesson Subject Topic To Optimize Grade XI Students' Cognitive Comprehension,” J. Pendidik. Sains, vol. 19, no. 2, pp. 57-63, 2017.

[15] M. Masood and M. Thigambaram, "The Usability of Mobile Applications for Preschoolers," Procedia - Soc. Behav. Sci., vol. 197, no. February, pp. 1818-1826, 2015. 